\title{
The therapeutic function literature with elderly: ressignification from memory
}

\begin{abstract}
The present study aimed to identify and analyze the discourses of the elderly that demand literacy assistance in non - governmental organization located in the west region of greater São Paulo, Brazil on the reading of literary texts. To achieve this goal, we use an intervention research, through reading workshops. The group of participants was composed of 7 elderly people of both genders with ages ranging from 65 to 87 years. The data that emerged from the workshops were audiographed and transcribed for later analysis. The data analysis was carried out with the support of the Software Interface for Multidimensional Analyzes of Texts and Questionnaires (IRAMUTEQ). It was observed in this group the importance of remembering and simultaneously re-meaning the past. It was considered that there is a need for social programs that consider that the elderly population presents losses that need to be elaborated
\end{abstract}

Keywords: aging, discurse, intervention, literary, memory, reading, ressignification
Volume 3 Issue I - 2018

\section{Janaína da Silva Gonçalves Fernandes, Leda Maria Codeço Barone, Márcia Siqueira de Andrade}

Department of Post-Graduation in Educational Psychology, Centro Universitário Unifieo, Brazil

Correspondence: Janaína da Silva Gonçalves Fernandes, Department of Post-Graduation in Educational Psychology, Centro Universitário Unifieo, Avenida: Franz Voegeli, 300, Vila Yara, Osasco, São Paulo, Brazil, CEP 06020-1 90 Tel 55(0I I)9400I-4926, Email janainagoncalves80@yahoo.com.br. ljanaina.fernandes@unifieo.br

Received: January 18, 2018 | Published: February 15, 2018

\section{Introduction}

The idea of studying the therapeutic function of literature with the elderly has arisen from the demands made by literacy students in a center in living together the elderly. These elderly people during the activities developed in the course complained of difficulty in memorizing what they were taught. At the same time, they observed the interest these same elderly showed in telling stories from their past, giving the impression that this activity enriched them and facilitated interaction with the group.

Another point that contributed to the interest in this theme came from contact with authors, who attribute therapeutic value to the reading of literary texts. For example, Petit ${ }^{1}$ considers reading an instrument capable of nurturing life and facilitating the construction and reconstruction of the person. The author of this article considers in spaces in crises those changes destabilize the person in its functional structure, being able to cause him an existential void, destructuring his way of accounting for his life. ${ }^{1}$ In this sense, aging can be considered as a space of crisis, since the elderly undergo an important transformation in the form of adjustment to life. The elderly face several losses at this point in life; loss of physical strength, work and loved ones. Losses that often need elaboration capable of leading them to re-signify the past and find new goals.

Thus, based on the observation of Petit ${ }^{1}$ that there is a therapeutic function in reading and hypothesizing that the reading of literature texts, for a group of elderly, can function as an element that favors the elaboration of losses suffered by aging and the re-signification from memory. Therefore, the present research aimed to identify and analyze the discourse of the elderly about the reading of literary texts. It was also intended to favor the development of the pleasure of the elderly in contact with the literary text.

\section{Material and methods}

It is a research / action, that is, at the same time that data is collected, it interferes with reality. The study was conducted at the
Headquarters unit of a non-governmental organization (NGO), which is an center in living together the elderly located in the west region of greater São Paulo, Brazil.

\section{Participantes}

Seven elderly people aged between 65 and 86 years participated in the study, one man and six women, all of whom demanded care at the NGO where the research was carried out, participants in the literacy course that covers the 1st to 4th year of elementary school . The inclusion criterion was established the elder who attended the literacy course.

These elderly people sought the Center for Coexistence for the Elderly by indicating friends and neighbors to participate in the activities of literacy and physical therapy classes in search of the following intentions: first to get together and talk to people to get distracted, and when they get peace they can forget their problems; second of practicing exercises. Thus, it is necessary to promote the removal of risk factors that cause diseases in old age, such as depression, as well as the maintenance of biological and social wellbeing.

Of the surveyed elderly, $57 \%$ are widowers; $29 \%$ married and 1 claimed to be divorced. Regarding the education level, $42 \%$ are in the 2nd year of elementary school; $29 \%$ the 4 th year and the same percentage for the 1 st year. The participants had free choice to participate or not of the present research, and there was no resistance and / or withdrawal to participate.

\section{Instruments}

Some literary texts were used as tools for data collection to be read to the group in order to understand the discourses of the elderly about the reading of literary texts (The bridge ${ }^{2}$ After the dance ${ }^{3}$ The three languages ${ }^{4}$ Cinderella $^{4}$ The eagle that almost became chicken ${ }^{5} \mathrm{e}$ The nightingale and the rose). ${ }^{6}$ In addition, the participants answered a questionnaire with socio-demographic data, including age, marital status and others. 


\section{Procedures \\ Data collection}

The research was approved by the Research Ethics Committee of the promoter institution and the participants signed an Consent Term. It is worth mentioning that the names of the people mentioned in the study, in order to protect them, are fictitious, chosen by the elderly themselves. Twelve Reading Workshop sessions were offered for a period of three months with a two-hour weekly meeting. We call the reading workshop meetings where the researcher reads literary text for a group, opening space for the free expression of each participant during and after reading, as well as encouraging the emergence of the prior knowledge of the participants as well as the discussion of issues mobilized in the group by reader. There was, therefore, a greater concern with the issues that may have transformative consequences for crisis areas. The sessions were audio-taped, and in each of them the group was arranged in a circle seeking to create a welcoming, protected and trusting environment.

\section{Data analysis}

For the analysis of the data seized through the depoiments obtained in the reading workshops, the software Interface for Multidimensional Analyzes of Texts and Questionnaires (IRAMUTEQ) was used, in its version 0.6 alpha 3, which was developed by Pierre Ratinaud professor of Toulouse University, as an auxiliary tool of the process of codification of the elements brought through the data collection. ${ }^{7}$ The program, besides allowing the quantitative lexical analysis that considers the word as a unit, also offers its contextualization in the corpus or depoiment. Each statement is composed of semantic contents, which is the database or corpus analyzed by IRAMUTEQ An analysis of the Descending Hierarchical Classification (DHC), which allows the analysis of the lexical roots and offers the contexts in which the classes are inserted, according to the text segment of the research corpus. ${ }^{8}$

\section{Results and discussion}

The analysis of the results was constituted by the corpus of 7 depoiments, which were processed by the IRAMUTEQ software. It was observed that there was a division of the corpus into 82 text segments (Sts), which is characterized by the excerpts from the depoiments containing 526 analyzable words. Figure 1 alludes to the distribution of the six classes that emerged, referring to the discourses that emerged from the reading of literary texts, seized from the cut of the 7 elders who participated in reading workshops.

The Dendrogram (Figure 1) shows the percentage of each class, followed by the number of text segments (STs) that make up the class description. On the side, it follows the titles of the classes that were categorized according to the inference of the semantic content of the participants' speeches, as well as the words of greater association with the said class, according to the coefficient obtained in the chisquare association test. It is noteworthy that this categorization was structured from the reading functions of literary texts proposed by Petit, ${ }^{1}$ Eco $^{9}$ and Candido $^{10}$ : Class 01: Humanizing Function; Class 02: Function of Education to Fado and Death; Class 03: Function Psychological; Class 4: Forming Function; Class 5: Social Function; Class 6: Therapeutic or Reparation Function.

In order to respect the DHC that emerged through the processing of the testimonials of the elder with the support of the IRAMUTEQ software, the presentation of the results and of the discussions is based on the division and hierarchy established by the program. Also presented are the relationships of the words that emerged in the classes among themselves, in the format of cuts of the corpus using the segments of more significant texts of each class.

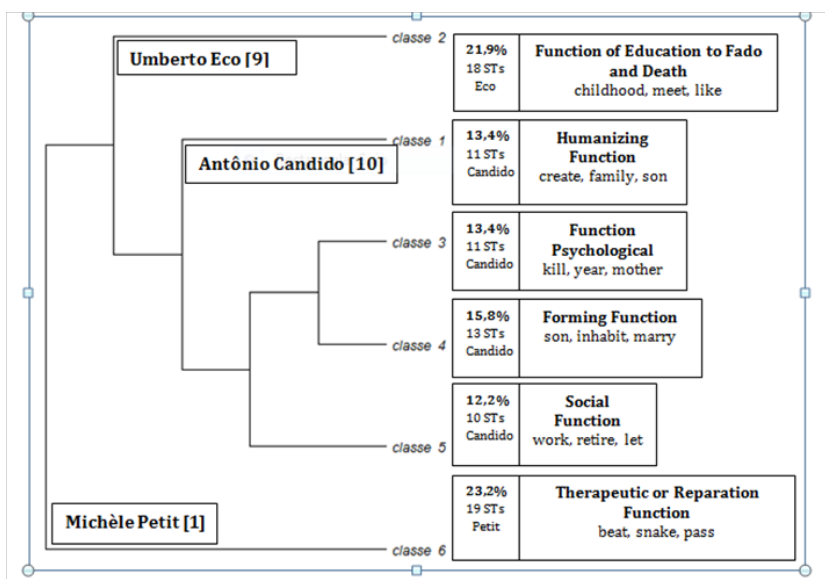

Figure I Dendrogram representative of the distributions in classes, percentage and analyzable words of the depoiments of the elderly.

\section{Class 6:Therapeutic or reparation function}

This class was structured with 19 STs, corresponding to $23.2 \%$ of explanatory power. It should be noted that this is the class with the greatest explanatory power in the sample of the surveyed elderly, among the contents of the other dendrogram classes (Figure 1) since this class is the basis for the formation of the others. In this way, the most significant representative of this group of elderly people are shown. Its semantic content suggests that reading to literary text is not a harmless experience since it often shows itself to imitate life, which is not free from adventures and dangers. Therefore, it can transform the thoughts and personality of those who take possession of it.

During the Reading Workshops, reading the text "The Bridge" by Barbieri and Vilela ${ }^{2}$ Martha crosses the bridge of history in her imaginary and travels to the past of her own history.

The stream reminded me that I was washing clothes with my grandmother, knocking them on the rocks and with a bridge where we bathed and snakes that seemed to play among the stones passing through the middle of our legs (Martha).

Petit $^{1}$ says that literature texts help the person produce meaning and utter an inner narrative, which enables the construction and reconstruction of himself. The text also, according to the author, facilitates the construction of a narrative that takes up the history of the person giving it a place in the world. Martha, remembering her youth and the walks in her grandmother's house, is rescuing her roots, rebuilding her history, which is primordial for the construction of meanings of her own life.

\section{Class 2: Function of education to fado and death}

This class was structured with 18 STs, which corresponds to $21.9 \%$ of explanatory power. Even though this class appears at the other end of the dendrogram (Figure 1) it is not opposed to class 6 (Therapeutic or Repairing Function) because it is derived from it. In addition, this class also has a significant explanatory power, being the second class with the highest quantitative value of STs. The content of this class 
is related to the idea that readers learn to deal with many of the nonmodifiable stories, since they have the lesson that people do not have the power to change many of the facts they encounter. This inference can be observed in the segment of text that emerged from the speech of an elderly woman, after reading the text "After the Dance" of Leo Tolstoy: ${ }^{3}$

I met two boys in my childhood and when they grew up, they disputed who was with me. I was married for 40 years to the one who threatened me with death, but I really liked the other. After I became a widow I found my childhood love, but I did not want it, because today I am no longer the same and I have an inferiority complex (Cecilia).

Through ambiguities and world reading, literary texts offer the personal free will for interpretations, identifications and projections. On the other hand, the narratives of the characters and the unmistakable facts show the impossibility of transforming the destinies of the characters by teaching readers to accept the irrefutable fatality of their tragedies. ${ }^{9}$ This can be observed in the discourse of the elderly Cecilia, who had the opportunity to ressignification her current feeling of self-devaluation, by means of the rescue of the memory of a time when it was disputed by two suitors.

Loren $z^{11}$ argues that given the close relationship between future and past, the recent change of idea in the future can be translated by a change of idea about the past. It emphasizes that the basic idea of progress is about being able to forge the future and make it better than the present and the past. This is something remarkable, since the idea of improving the past may be related to the reparation of injustices suffered or committed in the past.

In this sense, the perception of memory for Cecilia is not only a retrospective of life, but also the possibility of prospecting, that is, thinking of a forward-looking, planning-oriented, future-oriented memory that is yet to come. Memory, in and of itself, is not necessarily tied to the past, but rather to an affective group, to the collective, which constructs and retakes it. ${ }^{12}$

\section{Class I: Humanizing function}

This class was structured with 11 STs, corresponding to $13.4 \%$ of explanatory power. It can be observed in the dendrogram (Figure 1) that this class was derived from class 2 (Function of Education to Fado and Death) that derived respectively from the base of all classes (class 6, Therapeutic or Repair Function). The contents of this class are based on access to literary texts as one of the universal needs of human beings. Candido ${ }^{10}$ points out that this need to be met with the purpose of stimulating the exercise of reflection in the person, organizing his inner chaos by the influence of the organized structure existing in literary works, strengthening it to conditions create emotional, psychological and of action. In the narrative of the elderly John after reading the text "The three languages" of the brothers Grimm $^{4}$ one can see how he deals with the facts of his past and his future perspectives.

I worked all my life and raised my daughters, but the study made me very lack and that is why I went back to study, to learn everything that was not already I learned a long time ago (John).

It can therefore be inferred that by understanding his own history the person can finally face the complexity of the outside world by overcoming the constraints or denials of his humanitarian rights. ${ }^{10}$ Kuns, Pauline and Aprile ${ }^{13}$ point out that the participation of the elderly in activities that stimulate the use of memory and evokes positive memories can prevent and delay the onset of dementia states with favorable results for their health, well being, elevated self-esteem and, therefore, to improve their quality of life.

Candido $^{10}$ still points out that the reading of literary texts humanizes the man by presenting himself simultaneously in three aspects: a construction of autonomous objects with structure and meaning; a mode of expression; a mode of knowledge. In this way some functions are related to the humanizing function of the reading of literary texts, being: the social function, the formative function and the psychological function.

\section{Class 5: Social function}

This class was structured with $10 \mathrm{STs}$, corresponding to $12.2 \%$ of explanatory power. Its content is related to the social function of the reading of literary texts in which Candido ${ }^{10}$ says that the act of reading is not a harmless action, it can transform a personality or even a society, perhaps for that reason it is frightening by its character devastating risk of unpredictable risks. The following segment of text exemplifies this thought:

My husband would not let me work I got my first job at the age of 58 in the supermarket parking lot and that's where I retired (Martha).

The elderly Martha expressed this experience after reading the text "The Eagle that almost became a chicken"5 which may be suggested that although Martha was oppressed and socially excluded from the labor market, the effects of reading the literary texts provoked in her identification with the character. According to a study that sought to identify the view of the elderly in children's books, this public is perceived in both biological and psychosocial aspects as negative. ${ }^{14}$ Therefore, a reading of literary texts can enable possible escape and psychological resources to face the scenario that negativises the elderly person. Thus all types of literary works can reflect values and reflections on their readers, even those considered of less quality, but the choices of the texts must be in agreement with the specific interests of the group or of the person. ${ }^{10}$

\section{Class 4: Forming function}

This class was structured with 13 STs, which corresponds to $15.8 \%$ of explanatory power. Its content is related to the formative function of the literary texts in which Candido ${ }^{10}$ explains that literature helps the person to overcome the existing chaos, through its organized aesthetic structure, producing new meanings, confirms the essential features of humanization of man denouncing the urgency of solving certain adversities, to understand and position oneself in the society that is inserted. The following text segment exemplifies how the elderly Suely dealt with the abandonment of her daughter.

My daughter is married and inhabit in another city and does not come to see me. They advised me to write a letter to her and i wrote everything what wanted to say (Suely).

Learning and memory abilities tend to decline according advance to the people age ${ }^{15}$ but for Suely the reading is very important, even if it is not defined as a literary text. He says that even though he has difficulty reading and writing, he uses a portion of Bible readings to write a letter to his daughter who does not come to visit. Candido ${ }^{10}$ clarifies that literary texts are constructed following a model of coherence being an organized structure. This organization suggests that you promote an impression that causes a mental organization, 
make the interior and the vision of the world of the reader. The elderly Suely experiences a real chaos in their inner world and their binding relationships, a reading of literary texts presupposes a way for an overcoming of chaos, suggesting an organization for the space to acting of the messages sent by the texts, stimulating the production of new senses. Therefore, the reading of literary texts is important, for the formation of people during the learning of reading and writing, and in many different aspects, because through this type of language the person stops being just spectator and becomes author of their very existence. ${ }^{16}$

\section{Class 3: Function psychological}

This class was structured with 11 STs, corresponding to $13.4 \%$ of explanatory power. Its content is related to the psychological function of literary texts by enabling the person to strengthen himself and create emotional, psychological and action conditions so that his selfknowledge, confidence in his potentials can occur, thus preventing the mutilation of his self. ${ }^{10}$ The following text segment exemplifies the content of this class:

... he was traumatized and never was the same again. He was eighteen years and two years after my mother's death he killed himself (Suely)

The elderly Suely in her process of listening to the text "The Nightingale and the Rose" captured the dramatic tone of the love story. Collective memory is a phenomenon regroup that are situated at different levels of experience, at macro systemic levels or even a restricted group, be it a family, a school class or a professional association. Memories can be relatively simple, as they may be an important event that has marked the life of the group so well that members will remember it throughout their lives. ${ }^{17}$

Petit ${ }^{1}$ points out that in spaces in crises the changes destabilize the person in its functional structure, being able to cause him an existential emptiness, de-structuring his way of accounting for his life. In this sense, aging can be considered as a space of crisis, since the elderly undergo an important transformation in the configuration of adjustment to life. Thus the reading of literary texts can help the person to think, by means of his own structure, re-signifying it through the exteriorization of the most difficult feelings to deal with and elaborate.

From the discourses narrated by the elderly during the offering of the reading workshops, it was possible to verify the association of the reading of literary texts for this group with the theoretical foundations of authors such as the contributions of Petit ${ }^{1} \mathrm{Eco}^{9}$ and Cândido ${ }^{10}$ who study the functions of literature. Among these functions, the humanizing function proposed by Cândido ${ }^{10}$ stands out; the reparative or therapeutic study studied by Petit ${ }^{1}$ and the function of education to Fado and death highlighted by Eco. ${ }^{9}$

This study also presents in Table 1 the literary texts that were read for the elderly, showing what the researcher expected the elderly to understand from the texts and what was really re-signified by them.

Table I Literary texts used as an intervention tool with a group of elderly people

\begin{tabular}{|c|c|c|}
\hline Textos & Esperado & Ressignificação \\
\hline The bridge $^{2}$ & Working in set for development. & $\begin{array}{l}\text { Identification with excerpt from the story (drowning), association with the } \\
\text { object (bridge), memories of its roots. }\end{array}$ \\
\hline After the dance ${ }^{3}$ & $\begin{array}{l}\text { Deception, ethics, morality and } \\
\text { disenchantment. }\end{array}$ & Love of childhood, reencounter, inferiority complex, passion, betrayal, dance. \\
\hline The three languages ${ }^{4}$ & $\begin{array}{l}\text { Conflict with the father, abandonment, } \\
\text { unknown, reading the world. }\end{array}$ & $\begin{array}{l}\text { Health, loss, hard life, biblical message, surprise with attitude of rejection of } \\
\text { the character, revelation of violence against child, identifies with the energy } \\
\text { of the character to create and educate the child, disbelief with the story, } \\
\text { jokes (wheel and with crickets), work and study. }\end{array}$ \\
\hline Cinderella ${ }^{4}$ & $\begin{array}{l}\text { Multifaceted maternal figure, sibling conflict, } \\
\text { fetishism, fantasies. }\end{array}$ & Unpaid work, conflicts with the sons and the mother. \\
\hline $\begin{array}{l}\text { The eagle that almost } \\
\text { became chicken }{ }^{5}\end{array}$ & $\begin{array}{l}\text { Every man is born an eagle, to be free and } \\
\text { to fly. }\end{array}$ & Vision of the world, determination, opportunities. \\
\hline $\begin{array}{l}\text { The nightingale and } \\
\text { the rose }\end{array}$ & $\begin{array}{l}\text { Each one gives what he has in his heart, just } \\
\text { as each one receives with the heart he has. }\end{array}$ & Death \\
\hline
\end{tabular}

Kensinger $^{18}$ explains that memory for irrelevant events can be improved when new information reveals that these events are important. Therefore, these memories are malleable, so new information can update the priority and content of existing memory traces. These results demonstrate that the elderly population despite their particularities with diverse life histories results in a homogenous public with suffered losses that need to be elaborated, the issue of less effective memory raises a fear as to their future prospects, but on the other hand can - it was possible observe the importance that exists for these elderly, to remember and at the same time to re-significate the past.

\section{Conclusion}

Considering that the objective of this work was to identify and analyze the discourses of the elderly about the reading of literary texts, the results came to reinforce that the contact with these texts can favor the elaboration of the suffered losses, as well as the ressignification from memory and the development of the pleasure of reading.

It was possible to identify that the therapeutic or reparative function of the literature (23.2\%) emerged as the basis for the formation of the other classes presenting the greatest explanatory power in the sample of the elderly surveyed. In this way, the most significant representative 
elements of this group of elderly people are shown. The function of education to fado and death $(21.9 \%)$ also has a significant explanatory power.

It was found that the reading of literary texts according to the hypothesis raised by Petit ${ }^{1}$ is an instrument capable of nurturing life and facilitating the construction and reconstruction of the person. This fact leads the person to a full mental activity by exercising his memory, which requires this type of stimulus for the understanding of his present situation, having as consequence the adaptation to his reality. As a practical result we obtained: the evolution in the group's interaction, in the participation of the proposed activities, in the exercise of speech and listening, in respect to divergent opinions, in curiosity and pleasure in the search for new knowledge.

With these results one realizes that it is necessary for society to believe and trust that the elderly have potential as well as weaknesses; which need to be stimulated and protected; who have experiences that can be transmitted to the younger generations, enriching them with this. It is urgent to take into account this population when we observe the data that indicates the vertiginous increase of this population in our time, thinking in strategies that can help them in the maintenance and acquisition of learning.

The limitations of this study were due to the fact that many elderlys did not attended classes due to poor health and thus only seven were active participants in the "Reading Workshops". In any case, this study brought the benefit of clarity that we can use creativity, imagination and the make-believe to rescue the identity of the person by validating their life history, stimulating the interaction between persons through exchanges of ideas, thoughts and shared feelings and may be enriched with the continuity of research on teaching / learning for the elderly.

\section{Acknoweledgements}

None.

\section{Conflict of interest}

Authors declare that there are no conflicts of interest.

\section{References}

1. Petit M. A leitura em espaços de crise. Revista Brasileira de Psicanálise. 2006;40(3):149-167.
2. Barbieri S, Vilela F. A Ponte. Coleção Jeitos de mudar o mundo. Escala Educacional, São Paulo, Brazil; 2008.

3. Manguel A. Contos de amor do século XIX. Companhia das Letras, São Paulo, Brazil; 2007.

4. Grimm I, Contos e lendas dos Irmãos Grimm. In: Vol. I, Vol.II e Vol.III, Jácomo, editors. São Paulo, Brazil.

5. Alves R. Estórias de bichos. Editora Loyola. São Paulo, Brazil; 2006.

6. Wilde O. Contos completos. Landmark, São Paulo, Brazil; 2006.

7. Mutombo E. A bird's-eye view on the EC environmental policy framing. 10 years of Impact assessment at the commission: The Case of DG ENV: ICPP. 1st International Conference on Public Policy; Grenoble, France; 2013. p. 26-28.

8. Camargo BV, Justo AM. IRAMUTEQ: Um software gratuito para análise de dados textuais. Temas em Psicologia. 2013;21(2):513-518.

9. Eco U. Sobre algumas funções da literatura. In: U Eco, editor. Sobre a literatura. Editora Record. Rio de Janeiro, Brazil; 2003.

10. Candido A. O direito à literatura. Vários escritos. Duas Cidades, São Paulo, Brazil; 1995.

11. Lorenz C. Blurred lines. history, memory and the experience of time. International Journal for History, Culture and Modernity. 2014;2(1):43-62.

12. Sanches JJ, Vasconcelos MS. Pesquisa em psicologia social com a terceira idade. Revista de Psicologia da UNESP. 2017;9(2):168-171.

13. Kuns E, Paulino CA, Aprile MR. Memória e envelhecimento: caracterização em um grupo de idosos com doença vestibular. Revista Equilibrio Corporal e Saúde. 2015;5(2):15-24.

14. Ferreira CPDS, Canuto KF, Araújo KMLD, et al. A visão do envelhecimento, da velhice e do idoso veiculada por livros infantojuvenis. Saúde e Sociedade. 2015;24(3):1061-1075.

15. Derksen BJ, Duff MC, Weldon K, et al. Older adults catch up to younger adults on a learning and memory task that involves collaborative socia interaction. Memory. 2015;23(4):612-624.

16. Pessoa PS, Andrade MS, Barone LMC. A Literatura na Intervenção Psicopedagógica. Revista de Graduação USP. 2017;2(3):193-196.

17. Barash JA. O lugar da lembrança. Reflexões sobre a teoria da memória coletiva em Paul Ricoeur. Revista Memória em Rede. 2016;4(6):59-70.

18. Kensinger EA. The future can shape memory for the present. Trends in cognitive sciences. 2015;19(4):179-180. 